\title{
Perilaku Pertukaran Kalium (K) dalam Tanah, K Terangkut serta Produksi Jagung (Zea mays L.) Akibat Olah Tanah dan Pemupukan di Tanah Ultisol Gedung Meneng pada Musim Tanam Ketiga
}

\section{Potassium (K) Exchange Behavior in Soil, Harvested $K$ and Production of Corn (Zea mays L.) Affected by Tillage and Fertilizers in Ultisol Soil of Gedung Meneng at The $3^{\text {rd }}$ Planting Season}

\author{
Romando Lumbanraja ${ }^{1}$, Jamalam Lumbanraja ${ }^{{ }^{\star}}$, Hery Norvpriansyah ${ }^{1}$, dan Muhajir Utomo ${ }^{1}$ \\ ${ }^{1}$ Jurusan Agroteknologi, Fakultas Pertanian, Universitas Lampung. \\ Jl. Sumantri Brojonegoro 1, Bandar Lampung, 35145, Lampung, Indonesia \\ *Email: j.lumbanraja53@gmail.com, jamalam.lumbanraja@fp.unila.ac.id
}

Disubmit: 11 September 2019 Direvisi: 13 Desember 2019 Diterima: 10 Januari 2020

\begin{abstract}
Abstrak: Penelitian ini bertujuan untuk mengetahui: (1) pengaruh olah tanah dan pemupukan terhadap produksi (biomasa) dan kalium terangkut oleh tanaman jagung, (2) pengaruh perlakuan olah tanah dan pemupukan terhadap parameter kuantitas-intensitas $(\mathrm{Q} / \mathrm{l})$ kalium di dalam tanah, dan (3) korelasi parameter $\mathrm{Q} / \mathrm{I}$ kalium di dalam tanah dengan kalium terangkut dan biomassa jagung akibat perlakuan olah tanah dan pemupukan. Penelitian di lapang disusun dalam rancangan acak kelompok (RAK) dengan 3 kelompoksebagai ulangan. Perlakuan terdiri dari dua olah tanah (intensif dan minimum) dan dua pemupukan (tanpa pupuk dan dipupuk). Hasil penelitian ini menunjukkan bahwa (1) pemberian pupuk (NPK $400 \mathrm{~kg}$ ha-1 + Urea $200 \mathrm{~kg}$ ha-1 + Kompos $1 \mathrm{Mg}$ ha-1) berpengaruh nyata meningkatkan produksi jagung, biomassa dan $\mathrm{K}+$ terangkut panen jagung, tetapi pengaruh perlakuan olah tanah tidak berpengaruh nyata terhadap 3 variabel tersebut, (2) pengaruh perlakuan olah tanah dan pemupukan (dengan Uji-t) untuk perlakuan A (olah tanah minimum), B (olah tanah minimum + pupuk), $C$ (olah tanah Intensif) menunjukkan pengaruh yang tidak nyata terhadap parameter $\mathrm{Q} / \mathrm{I}) \mathrm{K}+$ yaitu adsorpsi kalium $(\Delta \mathrm{K} 0)$, aktifitas rasio kalium dalam keseimbangan (ARKe) dan potensi penyangga $K(P B C K)$ pada kedalaman $0-10 \mathrm{~cm}$ dan kedalaman $10-20 \mathrm{~cm}$, kecuali pada perlakuan D (oleh tanah intensif dengan pupuk), (3) kalium terangkut panen dan biomassa jagung menunjukkan korelasi yang tidak nyata dengan adsorpsi $\mathrm{K}+$ yang mudah tersedia $(\Delta \mathrm{K} 0$-non-spesifik adsorbed), aktivitas rasio kalium dalam keadaan keseimbangan dengan kation lain dalam larutan tanah (ARKe), kapsitas tukar kation (KTK), kapasitas penyangga kalium (PBCK) dan koefisien selektivitas (Kv).
\end{abstract}

Kata kunci: Jagung (Zea mays L.), Lahan kering, Pertukaran kalium, Pupuk organik dan Anorganik

\begin{abstract}
The objectives of this study are to determine: (1) the effect of tillage and fertilization on biomass and harvested $K$ of corn plants, (2) the effect of the tillage and fertilization on the quantity/intensity (Q/I) $K^{+}$parameters in the soil, and (3) the correlation between the $Q / I$ parameters and available potassium in the soil with harvested potassium and biomass of corn due to tillage and fertilization treatments. The field research was arranged in a randomized block design (3 block) with the treatments consisting of tillage (intensive and minimum) and fertilization (with and without fertilized). The results indicate that (1) the effect of fertilizer $(400 \mathrm{~kg} \mathrm{NPK} \mathrm{ha-1}+\mathrm{kg}$ ha-1 urea + Compost $1 \mathrm{Mg}$ ha-1) had a significantly affected on corn biomass, harvested $\mathrm{K}$, and corn production, on the other hand, the effect of the tillage treatments was not significantly affected the 3 corn variables, (2 the tillage and fertilization treatments for $A, B$, and $C$ (with $t$-Test) was not significantly affect the $Q /$ I parameters) $K^{+}$for potassium adsorption $\left(\Delta K_{0}\right)$, activity ratio of potassium in balance $\left(A R K_{e}\right)$ and buffer potential $\left.K\left(P B C_{K}\right)\right)$ at a depth of $0-10 \mathrm{~cm}$ compared to that of $10-20 \mathrm{~cm}$, except in treatment $D$ (by intensive soil with fertilizer), (3) Harvested $K$ and corn biomass were not significantly correlated with $K^{+}$adsorbed ( $\Delta K_{0}$-non specific adsorbed), activity ratio of potassium in a state of equilibrium with other cations in soil solution $\left(A R K_{e}\right)$, cation exchange capacity $(C E C)$, the potential buffering capacity of potassium $\left(P B C_{K}\right)$ and $K^{+}$selectivity coefficient $(K v)$.
\end{abstract}

Keywords: Corn (Zea mays L.), Organic and inorganic fertilizers, Potassium exchange, Upland 


\section{PENDAHULUAN}

Jagung merupakan bahan pangan pokok kedua setelah beras yang digunakan sebagai sumber karbohidrat di Indonesia dan sebagai bahan baku industri dan pakan ternak. Meningkatnya jumlah penduduk dan perkembangan industri saat ini akan berdampak langsung terhadap peningkatan konsumsi jagung. Total produksi jagung di Indonesia tahun 2016 mencapai $23.578 .413 \mathrm{Mg}$ dengan luas panen 4.444.369 ha, sementara total kebutuhan jagung tahun 2017 diperkirakan mencapai 27.951.959 Mg. Tingginya permintaan jagung sehingga perlu meningkatkan produksi sebesar 4.373.546 Mg dengan meningkatkan produktivitas jagung menjadi $5,20 \mathrm{Mg} \mathrm{ha}^{-1}$ atau dibutuhkan penambahan luas panen jagung sebesar 931.018 ha. Sedangkan pada tahun 2016 Provinsi Lampung tercatat memiliki luas panen tanaman jagung sebesar 340.200 ha dengan produktivitas $5,056 \mathrm{Mg} \mathrm{ha}^{-1}$. Produktivitas jagung di Provinsi Lampung masih jauh dibawah angka target yaitu 5,167 Mg ha-1 (BPS, 2017).

Usaha meningkatkan produksi sangat dibutuhkan dalam memenuhi tingginya permintaan jagung, antara lain dengan meningkatkan produktivitas jagung. Namun upaya meningkatkan produksi jagung menghadapi berbagai kendala, salah satunya yaitu kesuburan tanah, terutama lahan pertanaman jagung yang banyak dibudidayakan pada lahan sawah maupun lahan kering. Lahan kering di Provinsi Lampung didominasi oleh Tanah Ultisol. Tanah Ultisol memiliki tingkat kesuburan tanah yang rendah dicirikan dengan kandungan bahan organik (BO) yang sangat rendah, reaksi tanah yang masam, kejenuhan Al yang tinggi, kejenuhan basa yang rendah, dan tingkat produktivitas tanah yang rendah. Tanah Ultisol memiliki unsur hara makro seperti posfor dan kalium yang sering kahat sehingga menjadi salah satu penghambat bagi pertumbuhan tanaman (Hardjowigeno, 2010).

Oleh sebab itu peningkatan produksi jagung dapat dilakukan dengan cara intensifikasi. Salah satu bentuk intensifikasi yang dapat dilakukan yaitu dengan pemupukan, baik dengan pupuk organik maupun anorganik dan juga manajemen pengolahan tanah. Manajemen pengolahan tanah berupa olah tanah konservasi yaitu olah tanah minimum dan olah tanah konvensional dapat meningkatkan produktivitas tanah.

Kalium dibutuhkan tanaman untuk proses fotosintesis dan fiksasi $\mathrm{CO}_{2}$, transfer fotosintat ke berbagai pengguna serta hubungan dengan air dalam tanaman. Fungsi kalium yang lainnya adalah esensial dalam sintesis protein, penting dalam pemecahan karbohidrat yaitu dalam proses pemberian energi bagi tanaman, membantu dalam kesetimbangan ion tanaman, penting dalam translokasi logamlogam berat seperti $\mathrm{Fe}$, membantu dalam ketahanan terhadap penyakit dan iklim yang tidak menguntungkan (Winarso, 2005).

Ketersediaan $\mathrm{K}$ dalam tanah sangat dipengaruhi oleh faktor kuantitas, intensitas $\mathrm{K}$ dan kapasitas penyangga $\mathrm{K}$ atau potential buffering capacity $\left(\mathrm{PBC}^{\mathrm{K}}\right.$ ) (Hunsigi, 2011). Masalah ketersediaan $\mathrm{K}$ pada pertanaman jagung di Tanah Ultisol perlu diperhatikan. Jumlah kalium yang hilang melalui tanaman jagung sangat besar yaitu $172 \mathrm{~kg} \mathrm{ha}^{-1}$. Kehilangan unsur hara lainnya untuk tanaman yang sama yaitu N 260 $\mathrm{kg} \mathrm{ha}^{-1}$ dan P $46 \mathrm{~kg} \mathrm{ha}^{-1}$ Cooke (1985).

Beberapa cara yang dapat diterapkan untuk memperbaiki kualitas Tanah Ultisol yaitu dengan cara pengolahan tanah dan pemupukan anorganik. Pengolahan tanah dapat mempengaruhi jumlah bahan organik dan $\mathrm{N}$ tanah. Begitu juga, $\mathrm{K}$ di dalam larutan tanah akan terpengaruhi disamping proses penjerapan oleh mineral liat. Pengolahan tanah maupun akumulasi bahan organik dan karakteristik pertukaran $\mathrm{N}$ - 
$\mathrm{NH}_{4}{ }^{+}$dan atau $\mathrm{K}^{+}$banyak dilakukan, khususnya pada lahan kering daerah subtropis (Lumbanraja and Evangelou, 1994).

Dalam hubungan ini perlu dilakukan penelitian mengenai perilaku hara kalium yang berkaitan dengan tanaman jagung akibat pengolahan tanah dan pemupukan di Tanah Ultisol. Oleh sebab itu penelitian ini dilakukan untuk mengetahui pengaruh pengolahan tanah dan kombinasinya dengan pupuk anorganik terhadap perilaku kalium dalam tanah dan serapan pada tanaman jagung di Tanah Ultisol. Penelitian ini bertujuan untuk mengetahui pengaruh olah tanah dan pemupukan terhadap peningkatan biomassa dan kalium terangkut oleh tanaman jagung, kuantitas dan intensitas unsur hara kalium di dalam tanah, dan mengetahui korelasi antara parameter $\mathrm{Q} / \mathrm{l}$ dengan kalium tersedia di dalam tanah dan kalium terangkut oleh tanaman jagung akibat perlakuan olah tanah dan pemupukan.

\section{METODE PENELITIAN}

Penelitian yang dilakukan yaitu penelitian pertanaman jagung di Laboratorium Lapang Terpadu Universitas Lampung dan analisis tanah tanaman di Laboratorium IImu Tanah Universitas Lampung. Penelitian penanaman jagung ini dilaksanakan menggunakan Rancangan Acak Kelompok (RAK) terdiri dari 4 perlakuan dengan 4 kelompok. Perlakuan yang diterapkan terdiri dari 2 faktor yaitu sistem olah tanah (T) dan pemupukan $(P)$. Sistem olah tanah terdiri dari olah tanah minimum (T0) dan olah tanah intensif (T1). Sedangkan aplikasi pupuk terdiri dari tanpa pupuk (P0), dengan pupuk (P1). Data tanaman produksi jagung, biomassa dan serapan $\mathrm{K}$ (tanaman jagung) diuji homogenitas ragam dengan uji Barlet, aditivitas data dengan uji Tukey. Pengaruh dari seluruh perlakuan diuji menggunakan uji $\mathrm{F}$ dilanjutkan analisis ragam dan uji Beda Nyata Terkecil (BNT). Sedangkan untuk mengetahui hubungan parameter $Q /$ / dengan serapan tanaman dilakukan uji korelasi. Daftar perlakuan yang dilakukan meliputi: A. Olah Tanah Minimum + Tanpa pemupukan, B: Olah Tanah Minimum + Aplikasi pupuk (NPK $400 \mathrm{~kg} \mathrm{ha}^{-1}+$ Urea $200 \mathrm{~kg} \mathrm{ha}^{-1}+$ kompos $\left.1 \mathrm{Mg} \mathrm{ha}^{-1}\right)$, C. Olah Tanah Intensif + Tanpa pemupukan dan D. Olah Tanah Intensif + Aplikasi pupuk (NPK $400 \mathrm{~kg}+$ Urea $200 \mathrm{~kg}+$ kompos $1 \mathrm{Mg} \mathrm{ha}^{-1}$ ).

Analisis tanah yang dilakukan yaitu: $\mathrm{N}$-total (metode Kjeldhal), P-tersedia (metode Bray-1), K-dd (pengekstrak $1 \mathrm{~N} \mathrm{C}_{2} \mathrm{H}_{7} \mathrm{NO}_{2} \mathrm{pH}$ 7), C-organik (Walkey dan Black), dan KTK (pengekstrak $1 \mathrm{~N} \mathrm{C}_{2} \mathrm{H}_{7} \mathrm{NO}_{2} \mathrm{pH} 7$ ), $\mathrm{pH}$ tanah aktual dan potensial $(1: 2,5)$, serta perilaku jerapan unsur hara kalium menggunakan metode Quantity/ Intensity khusus untuk top soil dan sub soil. Sementara itu, analisis $\mathrm{K}$ jaringan tanaman dilakukan dengan cara pengabuan kering kemudian dilarutan sampai volume $100 \mathrm{ml}$ dalam labu ukur. Selanjutnya, K ditetapkan menggunakan flamephotometer.

Metode quantity- intensity (Q/I) kalium

Analisis (Q/I) dilakukan menggunakan modifikasi prosedur yang digunakan oleh (Beckett, 1964). Tanah top soil dan sub soil dikering udara dan diayak lolos ayakan $2 \mathrm{~mm}$. Prosedur analisis Q/I yang dilakukan yaitu: sampel tanah $5 \mathrm{gr}$ ditempatkan ke dalam $50 \mathrm{ml}$ tabung sentrifuse, ditambahkan $50 \mathrm{ml}$ larutan seri $0,005 \mathrm{M} \mathrm{CaCl}_{2}$ dengan konsentrasi $\mathrm{KCl}$ dari $0 ; 0,5 ; 1,0 ; 1,5 ; 2,0$; dan $3,0 \mathrm{mmol} \mathrm{L}^{-1}$. Selanjutnya tanah dikocok selama 2 jam dan disentrifuse selama 15 menit dengan kecepatan 3000 rpm. Setelah larutan terkumpul dilakukan analisis $\mathrm{K}$ menggunakan 
Flamephotometer, serta $\mathrm{Ca}$ dan $\mathrm{Mg}$ menggunakan Atomic Absorption Spectrophotometer (AAS). Masing-masing perlakuan diulang sebanyak dua kali.

Dari metode Q/I K diperoleh kurva Q/I (Gambar 1) yang digambarkan oleh hubungan antara $\Delta K$ yang dijerap koloid tanah dan $A R^{K}$ sehingga diperoleh persamaan yang menggambarkan $\mathrm{K}$ di dalam tanah. Dimana nilai $\mathrm{AR}^{\mathrm{K}}{ }_{0}$ pada keseimbangan saat $\Delta \mathrm{K}=0$, nilai $\Delta \mathrm{K}_{0}$ diperoleh pada saat $A \mathrm{R}^{\mathrm{K}}=0$, dan $\mathrm{PBC}^{\mathrm{K}}$ dilihat dari kemiringan garis kurva.

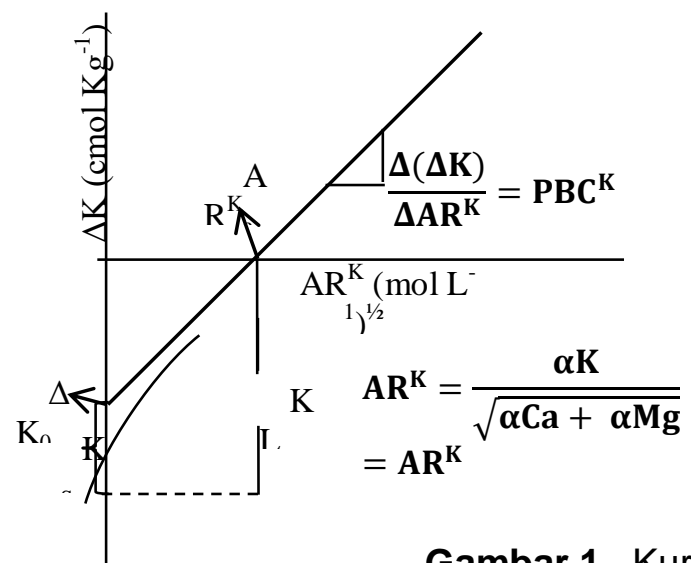

Gambar 1. Kurva ideal Q/l (Beckett, 1968)

Keterangan:

$\Delta \mathrm{K} \quad$ : Faktor Quantity (Q) (K)

$\mathrm{AR}^{\mathrm{K}}$ : Activity ratio atau faktor Intensit (I),

$\Delta \mathrm{K}_{0}$ : Kedudukan non-spesifik $\mathrm{K}$,

$\mathrm{AR}_{0}{ }_{0}$ : Keseimbangan activity ratio $\mathrm{K}$,

$\mathrm{PBC}^{\mathrm{K}}$ : Potential buffering capaciti (kapasitas penyangga $\mathrm{K}$ ).

$\mathrm{KL}$ : K labil yang dapat dipertukarkan,

$\mathrm{Ks} \quad$ : Kedudukan spesifik $\mathrm{L}\left(=\mathrm{K}_{\mathrm{L}}-\Delta \mathrm{K}_{0}\right)$

Berdasarkan gambar 1 nilai $\mathrm{AR}^{\mathrm{K}}$ dan $\Delta \mathrm{K}$ diperoleh dari hasil perhitungan sebagai berikut:

Faktor Quantity $(\mathrm{Q}) \mathrm{K}(\Delta \mathrm{K})$ merupakan jumlah $\mathrm{K}$ dijerap atau dilepas oleh tanah ketika tanah diberi larutan seri. $\Delta \mathrm{K}$ dihitung menggunakan rumus (1):

$$
\Delta \mathrm{K}=\mathrm{K}_{\text {seri }}-\mathrm{K}_{\text {di dalam larutan setelah dikocok }}
$$

Faktor Intensity $\mathrm{K}\left(\mathrm{AR}^{\mathrm{K}}\right)$ adalah hasil perhitungan dari pengukuran konsentrasi $\mathrm{K}, \mathrm{Ca}$, dan $\mathrm{Mg}$ dikoreksi dari kesesuaian aktivitas ion $(\alpha) . \quad \mathrm{AR}^{\mathrm{K}}$ ditentukan menggunakan rumus (2):

$$
\mathrm{AR}^{\mathrm{K}}=\frac{\alpha \mathrm{K}}{\sqrt{\alpha \mathbf{C a}+\alpha \mathrm{Mg}}}
$$

$\alpha \mathrm{K}, \mathrm{\alpha Ca}, \mathrm{aMg}$ dihitung menggunakan rumus:

$\alpha=\gamma M$

dimana: M: konsentrasi ( $\left.\mathrm{mol} \mathrm{L}^{-1}\right)$, $\alpha$ : activity ion, dan $\mathrm{\gamma}$ : Activity coefficient

Activity coefficient $(\mathrm{Y})$ dihitung berdasarkan pada parameter kekuatan ion (I). Kekuatan ion (I) (mol L-1) dihitung menggunakan rumus (4) oleh Griffin dan Jurinak 
(Ajiboye et al. 2015), dany dihitung menggunakan teori Debye- Huckel (Lindsay, 1979; Lumbanraja, 2017) rumus (5):

$$
\begin{aligned}
& I=1 / 2\left(C_{+} z^{2}+C \cdot z^{2}\right) \\
& \log y i=-A Z i^{2} \sqrt{I}
\end{aligned}
$$

$$
\gamma \mathrm{i}=10^{-\mathrm{AZi}^{2} \sqrt{\mathrm{I}}}
$$

dimana : $\mathrm{A}=$ konstanta $(0,504), \mathrm{Z}=$ Muatan ion, $\mathrm{I}=$ kekuatan ion, $\mathrm{C}_{+}=$Konsentrasi kation, $C_{.}=$Konsentrasi anion

Nilai koevisien vanselow (Kv) menunjukkan afinitas penjerapan kation ke dalam koloid tanah. Kv dihitung menggunakan persamaan Evangelou dan Philips (1987) rumus:

$$
\mathrm{PBC}^{\mathrm{K}}=1 / 2 \mathrm{Kv} \mathrm{KTK} \quad \text { jadi } \quad \mathrm{Kv}=\frac{2 \mathbf{P B C}^{\mathrm{K}}}{\mathrm{KTK}}
$$

\section{HASIL DAN PEMBAHASAN}

\section{Sifat Kimia Tanah dan Produksi Jagung (Zea mays L.) di Lapangan Sifat Kimia Tanah}

Hasil analisis kimia tanah awal sebelum tanam dan akhir setelah panen dapat dilihat pada Tabel 1. Tanah Ultisol Gedung Meneng memiliki pH tanah yang agak masam ( $\mathrm{pH} 5,5-6,0)$, dan ketersediaan unsur hara di dalam tanah seperti nilai $\mathrm{N}$ Total tanah tergolong rendah, $\mathrm{P}$ tersedia tanah tergolong tinggi, KTK rendah dan nilai C-total tanah tergolong rendah. Nitrogen total pada setiap perlakuan mengalami peningkatan pada setiap perlakuan. Kandungan $\mathrm{N}$-total hasil analisis awal yaitu $0,12 \%-0,19 \%$ yang tergolong rendah, sedangkan hasil analisis akhir $\mathrm{N}$-total tergolong rendah yaitu antara 0,21\%-0,235.

Penurunan kandungan $\mathrm{P}$ diduga karena $\mathrm{P}$ yang tersedia di dalam tanah banyak diserap oleh tanaman untuk proses pertumbuhan tanaman jagung. Pelapukan bahan organik di daerah tropika basah sangat tinggi sehingga penurunan kandungan C-organik tanah berlangsung cepat yang berakibat kandungan bahan organik rendah (Nursyamsi dan Suprihatin, 2005).

Nilai KTK tanah awal maupun akhir rendah. Penurunan KTK dan KB dari tanah awal ke tanah akhir dapat disebabkan oleh kation-kation basa seperti $\mathrm{K}^{+}, \mathrm{Ca}^{2+}, \mathrm{Mg}^{2+}$, $\mathrm{Na}^{+}$diserap oleh tanaman, selain itu $\mathrm{K}^{+}$yang mudah tercuci akibat curah hujan yang cukup tinggi. Tanah Ultisol merupakan jenis tanah yang telah mengalami pelapukan tinggi sehingga memiliki KTK dan KB rendah Prasetyo dan Suriadikarta (2006); Hermawan (2014). Ultisols juga miskin hara $\mathrm{P}$ dan kation-kation dapat dipertukarkan seperti $\mathrm{Ca}, \mathrm{Mg}$, Na dan $\mathrm{K}$ sehingga berakibat pada KTK rendah dan peka erosi ( Sudaryono, 2009). 
Tabel 1. Hasil analisis sifat kimia tanah awal dan akhir lapisan tanah top soil pada Lahan Tanaman Jagung

\begin{tabular}{|c|c|c|c|c|c|c|c|c|}
\hline \multirow{2}{*}{\multicolumn{2}{|c|}{ Jenis Analisis }} & \multicolumn{7}{|c|}{ Perlakuan } \\
\hline & & \multirow{2}{*}{$\begin{array}{l}\mathbf{A} \\
5,67 \mathrm{AM}\end{array}$} & \multirow{2}{*}{$\begin{array}{r}\text { B } \\
5,71\end{array}$} & \multirow[b]{2}{*}{ AM } & \multirow{2}{*}{$\begin{array}{r}\text { C } \\
5,86\end{array}$} & \multicolumn{3}{|c|}{ D } \\
\hline \multirow{2}{*}{$\mathrm{pH}\left(\mathrm{H}_{2} \mathrm{O}\right)$} & Awal & & & & & AM & 5,69 & AM \\
\hline & Akhir & 5,62 AM & 5,80 & AM & 5,80 & AM & 5,84 & AM \\
\hline \multirow{2}{*}{$\mathrm{pH}(\mathrm{KCl})$} & Awal & $5,32 \mathrm{M}$ & 5,33 & $M$ & 5,38 & $\mathrm{M}$ & 5,30 & $\mathrm{M}$ \\
\hline & Akhir & $5,47 \quad M$ & 5,18 & $\mathrm{M}$ & 5,29 & $\mathrm{M}$ & 5,44 & $\mathrm{M}$ \\
\hline \multirow{2}{*}{ N-Total (\%) } & Awal & $0,14 R$ & 0,19 & $\mathrm{R}$ & 0,16 & $\mathrm{R}$ & 0,13 & $\mathrm{R}$ \\
\hline & Akhir & $0,13 R$ & 0,11 & $\mathrm{R}$ & 0,11 & $\mathrm{R}$ & 0,12 & $\mathrm{R}$ \\
\hline \multirow{2}{*}{$\begin{array}{l}\text { P-Tersedia } \\
(\mathrm{ppm})\end{array}$} & Awal & $13,80 \mathrm{~T}$ & 17,50 & ST & 10,11 & $\mathrm{~T}$ & 12,83 & $\mathrm{~T}$ \\
\hline & Akhir & $10,55 \mathrm{~T}$ & 14,30 & $\mathrm{~T}$ & 7,63 & $\mathrm{~T}$ & 9,26 & $\mathrm{~T}$ \\
\hline \multirow{2}{*}{ C-total (\%) } & Awal & $1,88 R$ & 1,72 & $\mathrm{R}$ & 1,51 & $\mathrm{R}$ & 1,72 & $\mathrm{R}$ \\
\hline & Akhir & $1,68 R$ & 1,60 & $\mathrm{R}$ & 1,44 & $\mathrm{R}$ & 1,60 & $\mathrm{R}$ \\
\hline KTK & Awal & $9,5 \quad R$ & 8,50 & $\mathrm{R}$ & 8,50 & $\mathrm{R}$ & 7,60 & $\mathrm{R}$ \\
\hline$\left(\mathrm{cmol} \mathrm{kg}^{-1}\right)$ & Akhir & $8,70 \quad R$ & 8,30 & $\mathrm{R}$ & 7,80 & $\mathrm{R}$ & 8,40 & $\mathrm{R}$ \\
\hline
\end{tabular}

Keterangan: A (olah tanah minimum), B (olah tanah minimum + pupuk), C (olah tanah Intensif), D (olah tanah Intensif +pupuk. Angka yang diikuti huruf menyatakan $\mathrm{ST}=$ sangat tinggi; $\mathrm{T}=$ tinggi; $\mathrm{S}=$ sedang; $\mathrm{R}=$ rendah; $\mathrm{SR}=$ sangat rendah; $\mathrm{M}=$ masam; $\mathrm{AM}=$ agak masam; $\mathrm{N}=$ netral; $\mathrm{AA}=$ agak alkalis (Balai Penelitian Tanah, 2009).

\section{Pengaruh Sistem Olah Tanah dan Pemupukan terhadap Biomassa (Berat Kering) Tanaman Jagung}

Tabel 2. menunjukkan bahwa berat kering pada brangkasan, klobot dan berat total tertinggi pada pemberian NPK dengan dosis $400 \mathrm{~kg} \mathrm{ha}^{-1}$, Urea $200 \mathrm{~kg} \mathrm{ha}^{-1}$ dan $1 \mathrm{Mg} \mathrm{ha}^{-1}$ berturut-turut sebesar 6,47 $\mathrm{t} \mathrm{ha}^{-1}, 0,97 \mathrm{t} \mathrm{ha}^{-1}$, dan 7,45 $\mathrm{t} \mathrm{ha}^{-1}$ berbeda dengan tanpa pemberian pupuk yaitu berturut-turut $3,14 \mathrm{t} \mathrm{ha}^{-1}, 0,54 \mathrm{t} \mathrm{ha}^{-1}$ dan $3,72 \mathrm{t}$ ha $^{-1}$. Hal ini menunjukkan bahwa perlakuan tanpa diberi pupuk tidak mampu menghasilkan peningkatan yang signifikan terhadap berat kering tanaman. Penambahan berat kering tanaman masih tergantung dari pemberian pupuk anorganik dan organik yang diberikan. Hal tersebut disebabkan karena pupuk anorganik yang diberikan memiliki kandungan unsur hara $\mathrm{N}, \mathrm{P}$, dan $\mathrm{K}$ yang tinggi, sedangkan bahan organik memiliki kandungan unsur hara makro dan mikro yang rendah (Hardjowigeno, 2007).

Selain itu, produksi bahan kering atau penyerapan $\mathrm{N}$ oleh tanaman dipengaruhi oleh pemberian N. Hal ini dapat dilihat bahwa pemberian pupuk NPK lebih tinggi dibandingkan dengan perlakuan tanpa pemberian pupuk NPK dengan berat tajuk sebesar berturut-turut 257,72 g dan 149,63 g (Kriswantoro et al. 2016).

\section{Pengaruh Sistem Olah Tanah dan Pemupukan terhadap Produksi Tanaman Jagung}

Tabel 3 menunjukkan bahwa bobot pipilan jagung kering panen, kering oven dan bobot biji kadar air 14\% tertinggi pada perlakuan pemberian pupuk majemuk (NPK $400 \mathrm{~kg} \mathrm{ha}^{-1}+$ Urea $200 \mathrm{~kg} \mathrm{ha}^{-1}+1 \mathrm{Mg} \mathrm{ha}^{-1}$ sebesar berturut-turut 10,85 Mg ha , 6,99 $\mathrm{Mg} \mathrm{ha}^{-1}$ dan 10,09 $\mathrm{Mg} \mathrm{ha}^{-1}$ ) berbeda nyata bila biberi dengan perlakuan tanpa pupuk. Hal ini diduga karena adanya penambahan pupuk maka ketersediaan hara didalam tanah juga ikut meningkat. Meningkatnya hara di dalam tanah maka akan berpengaruh terhadap pertumbuhan tanaman jagung. Pemberian pupuk organik dan 
anorganik dapat meningkatkan produksi tanaman jagung baik itu panjang tongkol, lingkar tongkol dan bobot pipilan jagung (Frobel et al. 2013).

Tabel 2. Pengaruh olah tanah dan pemupukan terhadap berat kering tanaman jagung

\begin{tabular}{cccc}
\hline Perlakuan & \multicolumn{3}{c}{ Berat kering $\left(\mathbf{M g ~ h a} \mathbf{~}^{-1}\right)$} \\
\cline { 2 - 4 } & Brangkasan & Klobot & Total \\
\hline T0 (Olah Tanah Minimum) & 5,07 & 0,79 & 5,87 \\
\hline T1 (Olah Tanah Intensif) & 4,54 & 0,76 & 5,30 \\
\hline Uji F & tn & tn & tn \\
\hline P0 ( Tanpa Pupuk) & $3,14 \mathrm{~b}$ & $0,58 \mathrm{~b}$ & $3,72 \mathrm{~b}$ \\
\hline P1 (dipupuk) & $6,47 \mathrm{a}$ & $0,97 \mathrm{a}$ & $7,45 \mathrm{a}$ \\
\hline Uji F & ${ }^{*}$ & ${ }^{*}$ & \\
\hline BNT 5\% & 0,65 & 0,17 & 0,36 \\
\hline
\end{tabular}

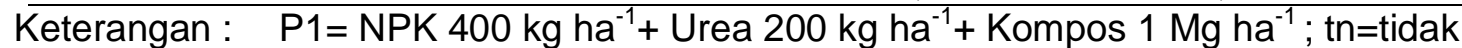
berbeda nyata pada taraf $5 \%$; * =berbeda nyata pada taraf $5 \%$; kolom yang diikuti oleh huruf yang sama tidak berbeda nyata pada uji BNT 5\%.

Tabel 3. Pengaruh olah tanah dan pemupukan terhadap produksi pipilan jagung per hektar

\begin{tabular}{cccc}
\hline Perlakuan & \multicolumn{3}{c}{ Bobot pipilan jagung (Mg ha ${ }^{-1}$ ) } \\
\cline { 2 - 4 } & $\begin{array}{c}\text { Biji kering } \\
\text { panen }\end{array}$ & $\begin{array}{c}\text { Biji kering } \\
\text { oven }\end{array}$ & $\begin{array}{c}\text { Biji kadar air } \\
\mathbf{1 4 \%}\end{array}$ \\
\hline T0 (Olah Tanah Minimum) & 8,90 & 5,73 & 8,28 \\
\hline T1 (Olah Tanah Intensif) & 7,84 & 5,04 & 7,29 \\
\hline Uji F & tn & tn & tn \\
\hline P0 ( Tanpa Pupuk) & $5,90 \mathrm{~b}$ & $3,78 \mathrm{~b}$ & $5,48 \mathrm{~b}$ \\
\hline P1 (dipupuk) & $10,85 \mathrm{a}$ & $6,99 \mathrm{a}$ & $10,09 \mathrm{a}$ \\
\hline Uji F & $\star$ & ${ }^{*}$ & 1,76
\end{tabular}

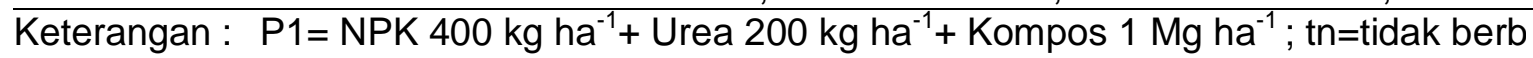
nyata pada taraf $5 \%$; * ${ }^{*}$ berbeda nyata pada taraf $5 \%$; kolom yang diikuti ole huruf yang sama tidak berbeda nyata pada uji BNT $5 \%$.

\section{Pengaruh Sistem Olah Tanah dan Pemupukan terhadap Serapan K Tanaman Jagung}

Tabel 4 menunjukkan bahwa serapan $\mathrm{K}$ tanaman jagung pada perlakuan tanpa pemberian pupuk nyata lebiih rendah dibandingkan dengan perlakuan pemberian pupuk (NPK $400 \mathrm{~kg}+$ Urea $200 \mathrm{~kg}$ ). Kandungan hara K brangkasan, biji dan total tanaman jagung tertinggi terdapat pada perlakuan pemberian pupuk yaitu sebesar $65,67 \mathrm{~kg} \mathrm{ha}^{-1}, 69,49 \mathrm{~kg} \mathrm{ha}^{-1}$, dan $135,17 \mathrm{~kg} \mathrm{ha}^{-1}$. Hal ini terjadi karena dengan adanya penambahan pupuk maka ketersediaan hara di dalam tanah juga ikut meningkat. Dengan adanya peningkatan kadar air maka serapan hara juga ikut meningkat. Hal ini Pemberian pupuk anorganik ke dalam tanah dapat menambah ketersediaan hara yang cepat bagi tanaman. Pasokan K yang cukup akan menjamin fungsi daun selama pertumbuhan buah dan jumlah gula dalam buah serta berperan dalam sintesis protein dan memacu konversi nitrat menjadi protein sehingga meningkatkan efisiensi $\mathrm{N}$ dalam tanah. Kandungan $\mathrm{K}$ di dalam jaringan yang cukup akan dapat mempertahankan kandungan air dalam jaringan pada kondisi tercekam sehingga tahan akan kekeringan dan serangan hama dan penyakit. Tingginya $\mathrm{K}$ yang terangkut pada perlakuan pemupukan sejalan dengan berat kering brangkasan, biji dan total bahan kering yang dihasilkan 
Tabel 4. Pengaruh sistem olah tanah dan pemupukan terhadap $\mathrm{K}$ terangkut oleh tanaman jagung

\begin{tabular}{cccc}
\multirow{2}{*}{ Perlakuan } & \multicolumn{3}{c}{ Serapan K (kg ha $\left.\mathbf{~}^{-1}\right)$} \\
\cline { 2 - 4 } & Brangkasan & Biji & Total \\
\hline T0 (Olah Tanah Minimum) & 51,41 & 56,35 & 107,76 \\
\hline T1 (Olah Tanah Intensif) & 46,41 & 52,22 & 97,52 \\
\hline Uji F & tn & tn & tn \\
\hline P0 ( Tanpa Pupuk) & $32,14 \mathrm{~b}$ & $37,97 \mathrm{~b}$ & $70,12 \mathrm{~b}$ \\
P1 (dipupuk) & $65,67 \mathrm{a}$ & $69,49 \mathrm{a}$ & $135,17 \mathrm{a}$ \\
\hline Uji F & $*$ & $*$ & $*$ \\
BNT 5\% & 6,52 & 11,32 & 16,42 \\
\hline P1 NPK 400
\end{tabular}

Keterangan : $\mathrm{P} 1=\mathrm{NPK} 400 \mathrm{~kg} \mathrm{ha}^{-1}+$ Urea $200 \mathrm{~kg} \mathrm{ha}^{-1}+\mathrm{Kompos}_{1} \mathrm{Mg} \mathrm{ha}^{-1} ; \mathrm{tn}=$ tidak berbeda nyata pada taraf $5 \%$; ${ }^{*}=$ berbeda nyata pada taraf $5 \%$; kolom yang diikuti oleh huruf yang sama tidak berbeda nyata pada uji BNT 5\%.

\section{Pengaruh Sistem Olah Tanah dan Pemupukan terhadap Perilaku Pertukaran Unsur Hara Kalium di dalam Tanah}

\section{Sifat Kimia pada lahan pertanaman jagung}

Sifat kimia tanah top soil dan sub soil setelah panen menunjukkan bahwa nilai $\mathrm{pH}\left(\mathrm{H}_{2} \mathrm{O}\right)$ tergolong dalam kriteria agak masam. Nilai $\mathrm{pH}$ untuk kedalaman 0-10 $\mathrm{cm}$ lebih rendah dibandingkan dengan kedalaman $10-20 \mathrm{~cm}$.

Tabel 5. Sifat Kimia pada lahan pertanaman jagung

\begin{tabular}{|c|c|c|c|c|c|c|}
\hline \multirow{2}{*}{ Perlakuan } & \multirow{2}{*}{$\begin{array}{l}\text { Kedalaman } \\
(\mathrm{cm})\end{array}$} & \multirow{2}{*}{$\begin{array}{l}\text { C-total } \\
(\%)\end{array}$} & \multicolumn{2}{|c|}{$\mathrm{pH}(1: 2)$} & \multirow{2}{*}{$\begin{array}{c}\mathrm{K}^{+} \\
\left(\mathrm{cmol} \mathrm{kg}^{-1)}\right.\end{array}$} & \multirow{2}{*}{$\begin{array}{l}\text { KTK } \\
\left(\mathrm{cmol} \mathrm{kg}^{-1)}\right.\end{array}$} \\
\hline & & & $\mathrm{H}_{2} \mathrm{O}$ & $\mathrm{KCl}$ & & \\
\hline \multicolumn{7}{|l|}{ Tanpa pupuk } \\
\hline $\begin{array}{l}\text { Olah tanah } \\
\text { minimum }\end{array}$ & $\begin{array}{c}0-10 \\
10-20\end{array}$ & $\begin{array}{l}2,11 \mathrm{~S} \\
1,47 \mathrm{R}\end{array}$ & $\begin{array}{l}5,62 \text { AM } \\
6,14 \text { AM }\end{array}$ & $\begin{array}{l}5,47 \mathrm{M} \\
5,58 \mathrm{M}\end{array}$ & $\begin{array}{l}0,66 \mathrm{R} \\
0,77 \mathrm{R}\end{array}$ & $\begin{array}{l}8,70 \mathrm{R} \\
8,40 \mathrm{R}\end{array}$ \\
\hline $\begin{array}{l}\text { Olah tanah } \\
\text { intesif }\end{array}$ & $\begin{array}{c}0-10 \\
10-20\end{array}$ & $\begin{array}{l}1,54 \mathrm{R} \\
1,54 \mathrm{R}\end{array}$ & $\begin{array}{l}5,80 \mathrm{AM} \\
6,09 \mathrm{AM}\end{array}$ & $\begin{array}{l}5,29 \mathrm{M} \\
5,39 \mathrm{M}\end{array}$ & $\begin{array}{l}0,53 R \\
0,40 R\end{array}$ & $\begin{array}{l}7,80 \mathrm{R} \\
7,00 \mathrm{R}\end{array}$ \\
\hline \multicolumn{7}{|l|}{ Pupuk } \\
\hline $\begin{array}{l}\text { Olah tanah } \\
\text { minimum }\end{array}$ & $\begin{array}{c}0-10 \\
10-20\end{array}$ & $\begin{array}{l}1,74 \mathrm{R} \\
1,30 \mathrm{R}\end{array}$ & $\begin{array}{l}5,80 \mathrm{AM} \\
6,01 \mathrm{AM}\end{array}$ & $\begin{array}{l}5,18 \mathrm{M} \\
5,23 \mathrm{M}\end{array}$ & $\begin{array}{l}0,80 R \\
0,60 R\end{array}$ & $\begin{array}{l}8,30 R \\
6,90 R\end{array}$ \\
\hline $\begin{array}{l}\text { Olah tanah } \\
\text { intensif }\end{array}$ & $\begin{array}{c}0-10 \\
10-20\end{array}$ & $\begin{array}{l}1,27 \mathrm{R} \\
1,23 \mathrm{R}\end{array}$ & $\begin{array}{l}5,84 \text { AM } \\
5,93 \text { AM }\end{array}$ & $\begin{array}{l}5,44 \mathrm{M} \\
5,29 \mathrm{M}\end{array}$ & $\begin{array}{l}0,58 \mathrm{R} \\
0,43 \mathrm{R}\end{array}$ & $\begin{array}{l}8,40 \mathrm{R} \\
7,00 \mathrm{R}\end{array}$ \\
\hline
\end{tabular}

Keterangan:A (olah tanah minimum), B (olah tanah minimum + pupuk), C (olah tanah Intensif), D (olah tanah Intensif +pupuk. Angka yang diikuti huruf menyatakan $\mathrm{ST}=$ sangat tinggi; $\mathrm{T}=$ tinggi; $\mathrm{S}=$ sedang; $\mathrm{R}=$ rendah; $\mathrm{SR}=$ sangat rendah; $\mathrm{M}=$ masam; $\mathrm{AM}=$ agak masam; $\mathrm{N}=$ netral; $\mathrm{AA}=$ agak alkalis (Balai Penelitian Tanah, 2009).

Hasil analisis tanah setelah panen menunjukkan nilai KTK untuk kedalaman 0$10 \mathrm{~cm}$ lebih tinggi dibandingkan dengan kedalaman $10-20 \mathrm{~cm}$ walaupun nilai KTK masih tergolong dalam kriteria rendah untuk semua perlakuan.. Hal ini diduga karena adanya akumulasi bahan organik di permukaan tanah akibat pengunaan mulsa sebelumnya (musim pertama dan musim kedua) yang dapat menambah bahan organik tanah. Hal yang sama juga terlihat untuk kandungan $\mathrm{C}$ total dimana tanah topsoil $(0-10 \mathrm{~cm})$ lebih tinggi dibandingkan subsoil $(10-20 \mathrm{~cm})$ yang diduga adanya akumulasi pemberian mulsa yang dapat menambah bahan organik. Bahan 
organik tanah melalui fraksi-fraksinya memiliki pengaruh yang nyata terhadap pergerakan dan pencucian hara (Muzaiyanah dan Subandi, 2016).

Sedangkan dengan $\mathrm{K}$-dd rendah, kandungan $\mathrm{K}^{+}$dapat ditukar pada perlakuan olah tanah minimum lebih tinggi dibandingkan dengan sistem olah tanah intensif. Hal ini disebabkan pada sistem olah tanah minimum terdapat akumulasi bahan organik yang dihasilkan dari serasah gulma yang mengalami pelapukan yang dapat menyediakan unsur hara $\mathrm{K}^{+}$untuk pertumbuhan. Meningkatnya kesuburan tanah pada olah tanah minimum berkaitan dengan pendaur ulangan internal hara melalui pemanfaatan serasah gulma, rendahnya erosi dan pencucian hara. Dekomposisi serasah akan meningkatkan bahan organik tanah dan hara tanaman seperti N, P, K, Ca dan Mg (Utomo, 2002).

\section{Quantity-Intensity (Q/I) Kalium di Tanah Ultisol Gedung Meneng}

Hasil analisis pengukuran jerapan $\mathrm{K}^{+}$yang menggunakan metode $\mathrm{Q} / \mathrm{l}$ pada analisis tanah top soil dan subsoil yang menggambarkan kurva Q/I (Gambar 3, Gambar 4) dan nilai parameter Q/I masing-masing perlakuan dapat dilihat pada Tabel 6, dan uji student- $t$ (Tabel 7, Tabel 8 dan Tabel 9). Kurva Q/I menjelaskan hubungan antara ketersediaan quantity dan intensity $(\mathrm{Q} / \mathrm{l}) \mathrm{K}$ di dalam tanah yaitu antara $A R^{K}$ (faktor intensity) dan $\Delta \mathrm{K}$ (faktor quantity). Hubungan tersebut cukup menjelaskan bagaimana $\mathrm{K}$ di dalam tanah tergantung pada kuantitas tanah untuk menyediakan K. Pada Gambar 3 dan Gambar 4 dapat dilihat bahwa tanah pada semua perlakuan mengalami penjerapan $\mathrm{K}^{+}$yang dapat ditukar sehingga kurva berada diatas sumbu $\mathrm{X}$. Hal ini disebabkan karena pemberian pupuk $\mathrm{K}$ ke dalam tanah meningkatkan $\mathrm{K}$ dapat ditukar ke dalam $\left(\mathrm{K}_{\mathrm{dd}}\right)$ tanah sedangkan $(\mathrm{Ca}+\mathrm{Mg})_{\mathrm{dd}}$ tidak berubah. Sistem olah tanah minimum juga mengakibatkan akumulasi bahan organik dipermukaan yang mengandung $\mathrm{Ca}^{2+}, \mathrm{Mg}^{2+}, \mathrm{K}^{+}$, dan $\mathrm{Na}^{+}$.

Lebih lanjut pengaruh perlakuan terhadap $\mathrm{PBC}^{\mathrm{K}}$, dimana nilai $\mathrm{PBC}^{\mathrm{K}}$ pada perlakuan $\mathrm{A}$ (olah tanah minimum tanpa pemupukan) memiliki nilai $\mathrm{PBC}^{\mathrm{K}}$ lebih besar dibandingkan perlakuan yang lain . Nilai $\mathrm{PBC}^{\mathrm{K}}$ yang tinggi menunjukkan kemampuan tanah menyuplai $\mathrm{K}$ yang baik sedangkan $\mathrm{PBC}^{\mathrm{K}}$ tanah rendah menunjukkan bahwa tanah membutuhkan pemupukan yang sering. Adapun olah tanah yang dikombinasikan dengan pupuk NPK majemuk belum menunjukkan meningkatkan nilai $\mathrm{PBC}^{\mathrm{K}}$ di tanah. Hal ini berarti bahwa Tanah Ultisol Gedung Meneng perlu sering dilakukan pemupukan $\mathrm{K}$.

Nilai daya sangga kalium $\left(\mathrm{PBC}^{\mathrm{K}}\right)$ berbanding lurus dengan nilai koefisien selektivitas (Kv). Semakin tinggi $\mathrm{PBC}^{\mathrm{K}}$ maka $\mathrm{Kv}$ juga akan semakin tinggi. Dari Tabel 6 dapat dilihat pada umumnya nilai Kv pada tanah yang diberi perlakuan olah tanah minimum lebih tinggi dari pada perlakuan olah tanah intensif. Hal ini disebabkan pada olah tanah minimum memiliki kandungan bahan organik yang lebih tinggi sehingga dapat meningkatkan KTK sehingga daya jerap tanah terhadap $\mathrm{K}^{+}$ meningkat.

Pengaruh perlakuan terhadap koefisien selektivitas $\mathrm{K}^{+}(\mathrm{Kv})$, dimana perilaku $\mathrm{K}^{+}$ dalam tanah juga dapat dijelaskan dengan selektivitas tanah terhadap $\mathrm{K}^{+}(\mathrm{Kv})$. Dari tabel 6 dapat dilihat bahwa pada umumnya nilai $\mathrm{Kv}$ pada olah tanah minimum lebih tinggi daripada olah tanah intensif. Hal ini dapat dijelaskan bahwa tanah dengan olah tanah minimum lebih banyak mengikat $\mathrm{K}^{+}$daripada $\mathrm{Ca}^{2+}$ bila dibandingkan dengan olah tanah intensif. Selain itu, tingginya nilai Kv menggambarkan bahwa K 
yang diberikan melalui pemupukan $\mathrm{K}$ akan bertahan dari proses pencucian terutama tanah-tanah yang berada di daerah bercurah hujan tinggi (Lumbanraja et al.1993).

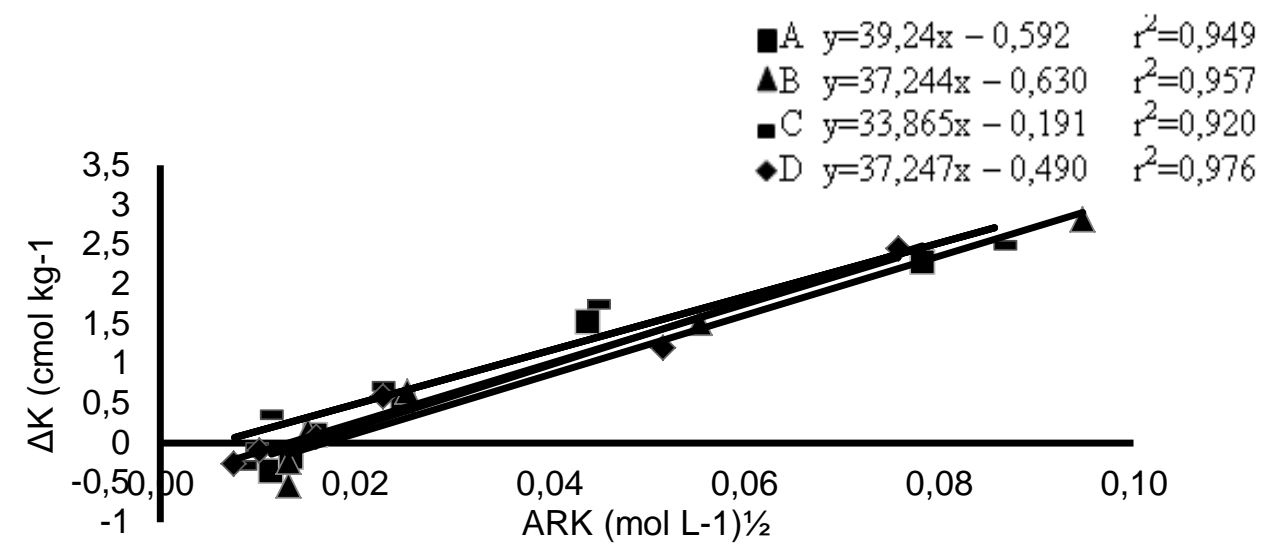

Gambar 3. Kurva Quantity-Intensitykalium pada dua sistem olah tanah dan pemupukan pada kedalaman 0-10 cm, Perlakuan A. Olah Tanah Minimum + Tanpa Pemupukan;B Olah Tanah Minimum + NPK: $400 \mathrm{~kg} \mathrm{ha}^{-1}$, Urea: $200 \mathrm{~kg} \mathrm{ha}^{-1}$, Kompos $1 \mathrm{Mg} \mathrm{ha}^{-1}$; C. Olah Tanah Intensif +Tanpa Pemupukan; D. Olah Tanah Intensif $+400 \mathrm{~kg} \mathrm{ha}^{-1}$, Urea: $200 \mathrm{~kg} \mathrm{ha}^{-1}$, Kompos $1 \mathrm{Mg} \mathrm{ha}^{-1}$.

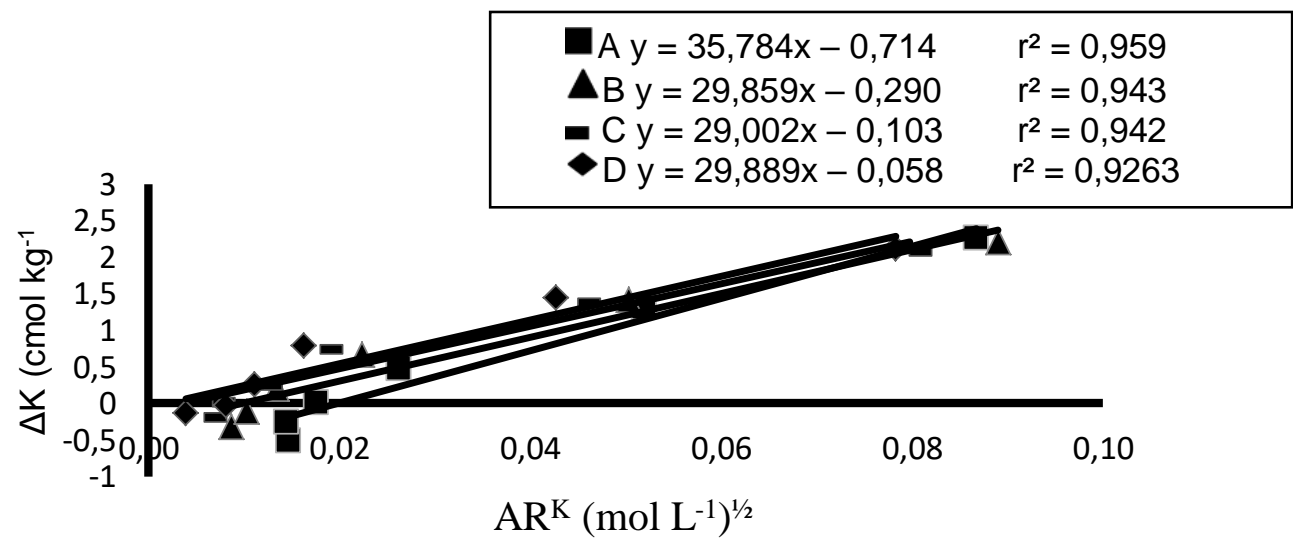

Gambar 4. Kurva Quantity-Intensitykalium pada dua sistem olah tanah dan pemupukan pada kedalaman 10-20 cm. Perlakuan A. Olah Tanah Minimum + Tanpa Pemupukan;B Olah Tanah Minimum + NPK: $400 \mathrm{~kg} \mathrm{ha}^{-1}$, Urea: $200 \mathrm{~kg} \mathrm{ha}^{-1}$, Kompos $1 \mathrm{Mg} \mathrm{ha}^{-1}$; C. Olah Tanah Intensif +Tanpa Pemupukan; D. Olah Tanah Intensif $+400 \mathrm{~kg} \mathrm{ha}^{-1}$, Urea: $200 \mathrm{~kg} \mathrm{ha}^{-1}$, Kompos $1 \mathrm{Mg} \mathrm{ha}^{-1}$.

Lebih lanjut, pada Tabel 7 dapat dilihat perbedaan pengaruh antara perlakuan terhadap kapasitas penyangga kalium ( $\mathrm{PBC}^{\mathrm{K}}$ ), kalium teradsorpsi dalam keadaan mudah dilepaskan $\left(\Delta \mathrm{K}_{0}\right)$, dan intensitas $\mathrm{K}^{+}$dalam keadaan kesimbangan $\left(\mathrm{AR}^{\mathrm{K}}{ }_{0}\right)$. Selain itu, nilai $P B C^{K}$ tanah dapat menggambarkan hubungan $\Delta K_{0}$ dengan $A R^{K}{ }_{0}$. Nilai intensitas pada kesimbangan $\left(A R^{k}\right)$ adalah nilai yang menggambarkan intensitas $\mathrm{K}^{+}$dalam keadaan kesimbangan. Tanah dengam sistem olah tanah minimum memiliki nilai $A R^{K}{ }_{0}$ lebih besar dibandingkan dengan $A R^{K}{ }_{0}$ pada sistem olah tanah intensif baik pada kedalaman $0-10 \mathrm{~cm}$ dan $10-20 \mathrm{~cm}$. Hal ini mengambarkan bahwa pemupukan $\mathrm{K}$ lebih efisien pada tanah dengan olah tanah minimum, terutama pada lahan kering dengan curah hujan yang tinggi. Pada uji Student- $t$ kedalaman $0-10 \mathrm{~cm}$ dan $10-20 \mathrm{~cm} \mathrm{AR^{ \textrm {K } }}{ }_{0}$. Perlakuan olah tanah minimum tanpa pupuk dibandingkan dengan olah tanah minimum dan olah tanah intensif yang 
diberi pupuk tidak bepengaruh nyata dan juga perlakuan olah tanah minimum diberi pupuk dibandingkan dengan perlakuan olah tanah intesif tanpa pupuk tidak berpengaruh nyata yang berarti belum dapat meningkatkan dan $\mathrm{AR}^{\mathrm{K}}{ }_{0}$ di dalam tanah. Pemberian pupuk $\mathrm{K}$ ke dalam tanah meningkatkan $A \mathrm{R}^{\mathrm{K}}{ }_{0}$ dan $\Delta \mathrm{K}_{0}$, tetapi tidak meningkatkan $\mathrm{PBC}^{\mathrm{K}}$ (Agustina, 2017).

Tabel 6. Nilai parameter $\mathrm{Q} / \mathrm{I}$ terpaut pada dua sistem olah tanah dan pemupukan pada kedalaman $0-10 \mathrm{~cm}$ dan $10-20 \mathrm{~cm}$

\begin{tabular}{|c|c|c|c|c|c|c|c|}
\hline Perlakuan & $\begin{array}{l}\text { Kedalaman } \\
\quad(\mathrm{cm})\end{array}$ & $\begin{array}{l}\text { PBC }^{\mathrm{K}} \\
\mathrm{cmolkg}^{-1} \\
\left(\mathrm{~mol} \mathrm{~L}^{-1}\right)^{1 / 2}\end{array}$ & $\begin{array}{r}\mathrm{AR}_{0}^{\mathrm{K}} \\
\mathrm{mol} \mathrm{L}^{-0,5}\end{array}$ & Kv & \multicolumn{3}{|c|}{$\mathrm{cmol} \mathrm{kg}^{-1}$} \\
\hline Tanpa Pupuk & & & & & & & \\
\hline Olah Tanah & $0-10$ & $39,24 R$ & 0,015 & 8,96 & 0,592 & 0,660 & 0,067 \\
\hline Minimum & $10-20$ & $35,78 R$ & 0,019 & 8,52 & 0,714 & 0,770 & 0,055 \\
\hline Olah Tanah & $0-10$ & $33,86 R$ & 0,005 & 8,68 & 0,191 & 0,536 & 0,344 \\
\hline $\begin{array}{l}\text { Intensif } \\
\text { Pupuk }\end{array}$ & $10-20$ & $29,00 \mathrm{R}$ & 0,003 & 8,28 & 0,103 & 0,409 & 0,305 \\
\hline Olah Tanah & $0-10$ & $37,24 \mathrm{R}$ & 0,016 & 8,97 & 0,630 & 0,809 & 0,179 \\
\hline Minimum & $10-20$ & $29,85 R$ & 0,009 & 8,65 & 0,290 & 0,605 & 0,314 \\
\hline Olah Tanah & $0-10$ & $37,24 R$ & 0,013 & 8,86 & 0,490 & 0,581 & 0,090 \\
\hline Intensif & $10-20$ & $29,88 R$ & 0,001 & 8,53 & 0,058 & 0,432 & 0,374 \\
\hline
\end{tabular}

Keterangan: $\Delta \mathrm{K}_{0}$ : Kedudukan non-spesifik $\mathrm{K} ; \mathrm{PBC}^{\mathrm{K}}$ : potential buffering capacitiy $\mathrm{K}$; $\mathrm{AR}_{\mathrm{e}}^{\mathrm{K}}$ : Keseimbangan activity ratio $\mathrm{K}, \mathrm{Kv}$ : koefisien vanselow; $\Delta \mathrm{K}_{0}$ : Kedudukan non-spesifik K, KL: K labil yang dapat dipertukarkan, dan Ks: Kedudukan spesifik $\mathrm{K}\left(=\mathrm{K} L-\Delta \mathrm{K}_{0}\right)$.Kriteria $\mathrm{PBC}^{\mathrm{K}}$ : (SR) sangat rendah (<20), $(R)$ rendah (20-50), (S) sedang (50-100), (T) tinggi ( $100-$ 200), dan (ST) sangat tinggi (.200) (Zharikova, 2004).

Nilai $\mathrm{AR}_{\mathrm{e}}^{\mathrm{K}}, \Delta \mathrm{K}_{0}, \mathrm{KL}$, dan $\mathrm{Ks}$ dari percobaan yang telah dilakukan diperoleh hasil yaitu tanah yang diberi perlakuan olah tanah minimum lebih tinggi dari pada perlakuan olah tanah intensif. Semakin tinggi $\Delta \mathrm{K}_{0}, \mathrm{KL}$, dan $\mathrm{Ks}$ (Tabel 6) maka akan semakin tinggi $\mathrm{K}$ tersedia di dalam tanah. Sehingga $\mathrm{K}$ yang dapat diserap oleh tanaman jagung juga akan semakin tinggi. Pada uji Uji student-t $\Delta \mathrm{K}_{0}$ (Tabel 8) perlakuan olah tanah tanpa pupuk maupun yang dikombinasikan dengan pupuk majemuk NPK tidak berbeda nyata. Hal ini menunjukkan bahwa olah tanah minimum yang dikombinasikan dengan pupuk majemuk NPK belum mampu meningkatkan $\Delta \mathrm{K}^{0}$ di dalam tanah. Sedangkan tanah yang diberi perlakuan $\mathrm{A}$ (olah tanah minimum) dengan perlakuan $\mathrm{C}$ ( olah tanah intensif) sangat berbeda nyata pada taraf $1 \%$. Hal ini dikarenakan $\mathrm{K}^{+}$dijerap oleh fraksi organik pada perlakuan olah tanah minimum dimana pada olah tanah minimum memiliki akumulasi bahan organik. Pengolahan tanah intensif seperti pada lahan pertanaman ubi kayu, akan menyebabkan terbukanya lahan dan penurunan kandungan bahan organik tanah.Penurunan kandungan bahan organik tanah ini akan berdampak pada penurunan kandungan humus tanah yang pada akhirnya juga akan berdampak pada penurunan nilai KTK tanah (Utomo, 2012).

Koloid humus mempunyai KTK paling besar dibandingkan dengan koloid liat. Koloid humus selain berfungsi sebagai tempat jerapan kation-kation, juga berperan sebagai sumber pembebasan unsur hara yang kemudian dapat dimanfaatkan untuk pertumbuhan dan perkembangan tanaman.

Uji student- $t \Delta \mathrm{K}_{0}, \mathrm{AR}_{\mathrm{Ke}}$, dan $\mathrm{PBC}_{\mathrm{K}}$ pada kedalaman $0-10 \mathrm{~cm}$ dibandingkan dengan pada $10-20 \mathrm{~cm}$ dapat di lihat padaTabel 9. Perlakuan olah tanah dan 
pemupukan untuk perlakuan $A, B$, dan $C$ (dengan Uji-t) tidak berpengaruh nyata terhadap parameter $\mathrm{Q} / \mathrm{I}) \mathrm{K}^{+}$yaitu adsorpsi kalium $\left(\Delta \mathrm{K}_{0}\right)$, aktifitas rasio kalium dalam keseimbangan $\left(A R_{K e}\right)$ dan potensi penyangga $K\left(P B_{K}\right)$ pada kedalaman $0-10 \mathrm{~cm}$ dibandingkan dengan pada $10-20 \mathrm{~cm}$, kecuali pada perlakuan $\mathrm{D}$ (oleh tanah intensif dengan pupuk)

Tabel 7. Uji Student-t pada parameter pengamatan $\mathrm{PBC}_{\mathrm{K}}, \Delta \mathrm{K}^{0}$, dan $\mathrm{ARK}_{\mathrm{e}}$ kedalaman $10-20$ $\mathrm{cm}$

\begin{tabular}{clrlll}
\hline \multirow{2}{*}{ Perlakuan } & \multicolumn{2}{l}{ T hitung } & & \multicolumn{3}{c}{ T tabel } \\
\cline { 2 - 5 } & $\mathbf{P B C}_{\mathbf{K}}$ & \multicolumn{1}{c}{$\Delta \mathbf{K}_{\mathbf{0}}$} & $\mathbf{A R}^{\mathbf{K}}{ }_{0}$ & $\mathbf{0 , 0 5}$ & $\mathbf{0 , 0 1}$ \\
\hline A VS B & $-14,55$ tn & $-11,06$ tn & 1,120 tn & 4,303 & 9,925 \\
A VS C & $-15,04$ tn & $25,27^{* *}$ & $7,58^{*}$ & & \\
A VS D & $-8,83$ tn & $-21,103$ tn & $-13,903$ tn & & \\
B VS C & $4,830^{*}$ & $5,168^{*}$ & $5,82^{*}$ & & \\
B VS D & $-0,865$ tn & $6,201^{*}$ & 2,22 tn & & \\
C VS D & $-2,51$ tn & $-3,11$ tn & $5,413^{*}$ & & \\
\hline
\end{tabular}

Keterangan: Perlakuan A. Olah Tanah Minimum + Tanpa Pemupukan;B Olah Tanah Minimum + NPK: $400 \mathrm{~kg} \mathrm{ha}^{-1}$, Urea: $200 \mathrm{~kg} \mathrm{ha}^{-1}$, Kompos $1 \mathrm{Mg} \mathrm{ha}^{-1}$; C. Olah Tanah Intensif + Tanpa Pemupukan; D. Olah Tanah Intensif + $400 \mathrm{~kg} \mathrm{ha}^{-1}$, Urea: $200 \mathrm{~kg} \mathrm{ha}^{-1}$, Kompos $1 \mathrm{Mg} \mathrm{ha}^{-1}$; * : Berbeda nyata pada taraf $5 \%$, ${ }^{* *}$ : Sangat berbeda nyata pada taraf $1 \%$, tn : Tidak berbeda nyata pada taraf $5 \%$.

Tabel 8. Uji Student-t pada parameter pengamatan $\mathrm{PBC}_{\mathrm{K}}, \Delta \mathrm{K}^{0}$, dan $\mathrm{ARK}_{\mathrm{e}}$ kedalaman $10-20$ $\mathrm{cm}$

\begin{tabular}{|c|c|c|c|c|c|}
\hline \multirow{2}{*}{ Perlakuan } & \multicolumn{3}{|l|}{ T hitung } & \multicolumn{2}{|c|}{$\mathrm{T}$ tabel } \\
\hline & $\mathrm{PBC}_{\mathrm{K}}$ & $\Delta \mathbf{K}_{0}$ & $A R_{0}^{K}$ & 0,05 & 0,01 \\
\hline$A \vee S B$ & $-14,55 \mathrm{tn}$ & $-11,06$ tn & 1,120 tn & 4,303 & 9,925 \\
\hline$A \vee S C$ & $-15,04 \mathrm{tn}$ & $25,27^{\star *}$ & $7,58^{*}$ & & \\
\hline A VS D & $-8,83 \mathrm{tn}$ & $-21,103 \mathrm{tn}$ & $-13,903 t n$ & & \\
\hline$B \vee S C$ & $4,830^{\star}$ & $5,168^{*}$ & $5,82^{*}$ & & \\
\hline$B \vee S D$ & $-0,865 \mathrm{tn}$ & $6,201^{*}$ & $2,22 \mathrm{tn}$ & & \\
\hline C VS D & $-2,51 \mathrm{tn}$ & $-3,11 \mathrm{tn}$ & $5,413^{*}$ & & \\
\hline
\end{tabular}

Keterangan: Perlakuan A. Olah Tanah Minimum + Tanpa Pemupukan;B Olah Tanah Minimum + NPK: $400 \mathrm{~kg} \mathrm{ha}^{-1}$, Urea: $200 \mathrm{~kg} \mathrm{ha}^{-1}$, Kompos $1 \mathrm{Mg} \mathrm{ha}^{-1}$; C. Olah Tanah Intensif +Tanpa Pemupukan; D. Olah Tanah Intensif $+400 \mathrm{~kg} \mathrm{ha}^{-1}$, Urea: $200 \mathrm{~kg} \mathrm{ha}{ }^{-1}$, Kompos $1 \mathrm{Mg} \mathrm{ha}^{-1} ;{ }^{*}$ : Berbeda nyata pada taraf $5 \%$, ** : Sangat berbeda nyata pada taraf $1 \%$, tn : Tidak berbeda nyata pada taraf $5 \%$.

Tabel 9. Uji Student-t pada parameter pengamatan $\mathrm{PBC}_{\mathrm{K}}, \Delta \mathrm{K}^{0}$, dan $\mathrm{ARK}_{\mathrm{e}}$ Top soi $(0-10)$ vs Sub soil $(10-20)$

\begin{tabular}{|c|c|c|c|c|c|}
\hline \multirow{2}{*}{ Perlakuan } & \multicolumn{2}{|l|}{ T hitung } & \multicolumn{3}{|c|}{$\mathrm{T}$ tabel } \\
\hline & PBC $_{K}$ & $\Delta \mathrm{K}_{0}$ & $A R_{0}^{K}$ & 0,05 & 0,01 \\
\hline$A_{(0-10)} V S A_{(10-20)}$ & $-8,06 \mathrm{tn}$ & $4,390^{\star}$ & $-0,30$ tn & 4,303 & 9,925 \\
\hline $\mathrm{B}_{(0-10)}$ VS $\mathrm{B}_{(10-20)}$ & $-39,87 t n$ & $-4,94 \mathrm{tn}$ & $-3,83$ tn & & \\
\hline $\mathrm{C}_{(0-10)}$ VS $\mathrm{C}_{(10-20)}$ & $-16,63 t n$ & $-1,61$ tn & $-1,720$ tn & & \\
\hline $\mathrm{D}_{(0-10)}$ VS $\mathrm{D}_{(10-20)}$ & $13,59^{* *}$ & $13,71^{* *}$ & $11,180^{* *}$ & & \\
\hline
\end{tabular}

Keterangan: Perlakuan A. Olah Tanah Minimum + Tanpa Pemupukan;B Olah Tanah Minimum + NPK: $400 \mathrm{~kg} \mathrm{ha}^{-1}$, Urea: $200 \mathrm{~kg} \mathrm{ha}^{-1}$, Kompos $1 \mathrm{Mg} \mathrm{ha}^{-1}$; C. Olah Tanah Intensif +Tanpa Pemupukan; D. Olah Tanah Intensif + $400 \mathrm{~kg} \mathrm{ha}^{-1}$, Urea: 
$200 \mathrm{~kg} \mathrm{ha}^{-1}$, Kompos $1 \mathrm{Mg} \mathrm{ha}^{-1} ;{ }^{*}$ : Berbeda nyata pada taraf $5 \%$, ** : Sangat berbeda nyata pada taraf $1 \%$, tn : Tidak berbeda nyata pada taraf $5 \%$.

\section{Uji Korelasi Hasil Analisis Tanah dan Tanaman dengan Parameter Q/I Kalium}

Hasil uji korelasi antara variabel yang disajikan pada Tabel 10, menjelaskan bahwa kalium terpanen dan biomassa jagung tidak nyata berkorelasi dengan adsorpsi $\mathrm{K}+$ yang dilepaskan ( $\Delta \mathrm{K} 0$-non-spesifik adsorbed), aktivitas rasio kalium dalam keadaan keseimbangan dengan kation lain dalam larutan tanah (ARKO), kapasitas penyangga kalium (PBCK) dan koefisien selektivitas (Kv). Hal ini diduga semakin tinggi nilai $\Delta K 0$ (semakin positif pada kurva $Q / I)$ maka semakin tinggi pula $K$ dapat ditukar (K-dd), KTK tanah, dan serapan $\mathrm{K}$ tanaman. $\Delta \mathrm{K} 0$ merupakan jumlah $\mathrm{K}$ yang sangat mudah ditukar sehingga semakin banyak jumlah $\mathrm{K}$ yang keluar dari tanah menunjukkan juga semakin banyak $\mathrm{K}$ yang dapat ditukar dan akan semakin banyak $\mathrm{K}$ yang dapat tersedia bagi tanaman sehingga akan semakin meningkat serapan K tanaman. Ajiboye et al. (2015) melaporkan bahwa rendahnya status mobile-K pada tanah yang diteliti menunjukkan bahwa tanah memiliki kemampuan rendah untuk mengisi K-dd hasil dari pengurangan oleh serapan tanaman. Kegiatan produksi tanaman akan sangat bergantung pada eksternal $\mathrm{K}$ dari sumber pupuk.

Pada tabel 10 juga menunjukkan PBCK berkorelasi positif dan tidak berpengaruh nyata terhadap serapan $\mathrm{K}$ serta biomassa tanaman. Hal ini dikarenakan PBCK pada tanah rendah sehingga $\mathrm{K}+$ yang berada dilarutan dan yang telah diserap tanaman maupun tercuci tidak dapat disuplai kembali oleh tanah. Rasnake dan Thompson (1976) menyatakan bahwa nilai PBCK yang rendah memerlukan dosis pemupukan dengan frekuensi yang relatif sering dibanding dengan PBCK yang lebih tinggi. Karena PBCK merupakan kemampuan tanah untuk mempertahankan $\mathrm{K}+$ di larutan tanah (Tisdale et al 1985).

Tabel 10. Uji korelasi antara $\Delta \mathrm{K}_{0}, \mathrm{Kdd}, \mathrm{KTK}, \mathrm{PBC}^{\mathrm{K}}$, dan serapan $\mathrm{K}$ tanaman jagung

\begin{tabular}{rllll}
\hline No & Uji korelasi & Persamaan & $\mathbf{r}$ & \\
\hline 1 & $\Delta \mathrm{K}_{0}$ VS serapan K tanaman & $\mathrm{y}=59,09+104,6 \mathrm{x}$ & 0,301 & $\mathrm{tn}$ \\
2 & $\mathrm{PBC}_{\mathrm{K}}$ VS serapan K tanaman & $\mathrm{y}=-62,11+4,469 \mathrm{x}$ & 0,083 & $\mathrm{tn}$ \\
3 & Kdd VS serapan K tanaman & $\mathrm{y}=-18,254+187 \mathrm{x}$ & 0,010 & $\mathrm{tn}$ \\
4 & $\mathrm{Kv}$ VS serapan K tanaman & $\mathrm{y}=-775,2+198,1 \mathrm{x}$ & 0,224 & $\mathrm{tn}$ \\
5 & $\mathrm{AR}_{\mathrm{K}}$ VS Serapan K tanaman & $\mathrm{y}=51,32+4552 \mathrm{x}$ & 0,358 & $\mathrm{tn}$ \\
6 & $\Delta \mathrm{K}_{0}$ VS biomassa tanaman & $\mathrm{y}=3,102+5,827 \mathrm{x}$ & 0,285 & $\mathrm{tn}$ \\
7 & $\mathrm{PBC}_{\mathrm{K}}$ VS biomassa tanaman & $\mathrm{y}=-3,199+0,238 \mathrm{x}$ & 0,07 & $\mathrm{tn}$ \\
8 & $\mathrm{Kdd}_{\mathrm{n}}$ V biomassa tanaman & $\mathrm{y}=-1.345+10,718 \mathrm{x}$ & 0,013 & $\mathrm{tn}$ \\
9 & $\mathrm{Kv}$ VS biomassa tanaman & $\mathrm{y}=-42,73+10,90 \mathrm{x}$ & 0,207 & $\mathrm{tn}$ \\
10 & $\mathrm{AR}$ VS biomassa tanaman & $\mathrm{y}=2,712+254,6 \mathrm{x}$ & 0,341 & $\mathrm{tn}$ \\
\hline
\end{tabular}

Keterangan: $\mathrm{tn}=$ tidak nyata pada taraf $5 \%$. 


\section{SIMPULAN}

Dari hasil penelitian dapat disimmpulkan bahwa: (1) Pemberian pupuk dengan dosis NPK $400 \mathrm{~kg}$ ha-1+ Urea $200 \mathrm{~kg}$ ha-1+ kompos $1 \mathrm{Mg}$ ha-1 berpengaruh nyata meningkatkan produksi jagung, biomassa dan $\mathrm{K}+$ terangkut panen jagung, tetapi pengaruh perlakuan olah tanah tidak berpengaruh nyata terhadap 3 variabel tersebut. (2) 2.Perlakuan olah tanah minimum dan pupuk menurunkan Potensi Penyangga kalium (PBCK) tetapi meningkatkan aktivitas kalium pada keseimbangan (ARK0), dan Kalium non-spesifik $(\Delta K 0)$ dibandingkan tanpa pemberian pupuk. (3) 3.Kalium tersedia dalam tanah, biomassa dan kalium terpanen jagung tidak nyata berkorelasi positif dengan parameter QI yaitu adsorpsi $\mathrm{K}+$ yang dilepaskan $(\Delta \mathrm{K} 0)$, aktivitas rasio kalium dalam keadaan keseimbangan dengan kation lain dalam larutan tanah (ARK0), kalium dapat ditukar (Kdd), kapasitas penyangga kalium (PBCK) dan koefisien selektivitas (Kv)..

\section{SANWACANA}

Terimaksih kepada Laboratorium Terpadu dan Sentra Inovasi Teknologi (LTSIT) Universitas Lampung.yang telah memberikan kontribusi dalam penyelesaian penelitian ini.

\section{DAFTAR PUSTAKA}

Agustina, W. 2017. Pengaruh Pupuk Organonitrofos dan Kombinasinya dengan Pupuk Anorganik terhadap Perilaku Pertukaran Kalium (K) dalam Tanah, serta Serapan K oleh Tanaman Tebu (Saccharum Officinarum L.) di Tanah Ultisol Gedung Meneng. Skripsi. Universitas Lampung. Lampung. $52 \mathrm{hlm}$.

Ajiboye, A. G., J. O. Azeez, and A. J. Omotunde. 2015. Potasssium Forms and Quantity- Intensity Relationship in some Wetland Soils of Abeokuta, Southwestern Nigeria. Archives of Agrotecnology and Soil Science 61(10): 1393-1408.

Beckett, P. H. T. 1964. Studies on Soil Potassium II. The 'Immediate' Q/I of Labile Potassium in The Soil. Journal of Soil Science 15(1): 9-23.

BPS. 2017. Data Produksi Jagung Indonesia pada Tahun 2016 (http://www.bps.go.id). Diakses pada 11 April 2019. $82 \mathrm{hlm}$.

Cooke, G.W 1985. Potassium in the agricultural systems of the humid tropics In Potassium in the Agricultural Systems of the Humid Tropics", Proceedings of the 19th Colloquium of the International Potash Institute held in Bangkok. Thailand: 21-28.

Evangelou, V. P. and R. E. Phillips. 1987. Sensitivity Analysis on the Comparison Between the Gapon and Vanselow Exchange Coefficients. Soil Science Social of America Journal 51: 1473-1479.

Frobel G. D ., J.J.M.R. Londok., R.A.V. Tuturoong dan W. B. Kaunang. 2013. Pengaruh Pemupukan Anorganik dan Organik terhadap Produksi Tanaman Jagung sebagai Sumber Pakan. Jurnal Zootek 32(5):5-7.

Hardjowigeno, S. 2010. Ilmu Tanah. Akademika Pressindo. Jakarta. 288 hal.

Hermawan, A. 2014. Perubahan Titik Nol Dan Efisiensi P Tanaman Jagung Pada Ultisol Akibat Pemberian Campuran Abu Terbang Batubara Dan Kotoran 
Ayam. [Disertasi]. Program Studi IImu IImu Pertanian. Fakultas Pertanian Universitas Sriwijaya. Palembang. $109 \mathrm{hlm}$.

Hunsigi, G. 2011. Potassium Management Strategies to Realize High Yield and Quanlity Of Sugarcane. Karnataka Journal of Agricultural Science 24(1): 45-47.

Kriswantoro, H., Etty S dan Syamsul B. 2016. Pemberian Pupuk Organik dan Pupuk NPK pada Tanaman Jagung Manis(Zea mays saccharata Sturt). Journal Klorofil 11(1): $1-16$.

Lindsay, W. L. 1979. Chemical Equilibria in Soils. John Wiley \& Sons. New York. 449 hlm.

Lumbanraja, J., M. Utomo dan Fitriati. 1993. Karakteristik jerapan amonium tanah pada tiga perlakuan pengolahan tanah dan pemupukan nitrogen. Prosiding Seminar Nasional IV: Budidaya Pertanian Olah Tanah Konservasi : 1-10.

Lumbanraja, J. 2017.Kimia Tanah dan Air: Prinsip Dasar dan Lingkungan. CV. Anugrah Utama Raharja. Lampung.

Lumbanraja, J. and V.P. Evangelou. 1994. Adsorption-desorption of potassium and ammonium at low cation concentrations in three Kentucky sub soil. Soil Science 157: 269-278.

Muzaiyanah, S., Subandi. 2016. Peranan Bahan Organik dalam Peningkatan Produksi Kedelai dan Ubi Kayu pada Lahan Kering Masam. Iptek Tanaman Pangan 11(2): 2-3.

Nursyamsi, D dan Suprihatin. 2005. Sifat-sifat Kimia dan Mineralogi Tanah serta Kaitannya dengan Kebutuhan Pupuk untuk Padi (Oryza sativa), Jagung (Zea mays), dan Kedelai (Glycine max). Bulgarian Agronomi 33(3): 40 - 47.

Prasetyo, B. H dan D. A. Suriadikarta. 2006. Karakteristik Potensi, dan Teknologi Pengelolaan Tanah Ultisol Untuk Pengembangan Pertanian Lahan Kering di Indonesia. Journal Litbang Pertanian 25(2): 39-47.

Rasnake, M., and G. W. Thomas. 1976. Potassium Status of Some Alluvial Soils in Kentucky. Soil Science Social of America Journal 40: 883-886.

Sudaryono. 2009. Tingkat Kesuburan Tanah Ultisol pada Lahan Pertambangan Batubara Sangatta, Kalimantan Timur. Jurnal Teknik Lingkungan 10(3): 337346.

Sutedjo, M. M. dan A. G. Kartasapoetra. 2010. Pengantar Ilmu Tanah: Terbentuknya Tanah dan Tanah Pertanian. Rineka cipta. Jakarta. $98 \mathrm{hlm}$.

Tisdale, S. L., W. L. Nelson, and J. D. Beaton. 1985. Soil Fertility and Fertilizers Fourth Edition. Mucmillan Publishing Company. New York. $754 \mathrm{hlm}$.

Utomo, M. 2002. Olah tanah konservasi untuk pengelolaan lahan berkelanjutan," Prosiding Seminar Nasional Budidaya Olah TanahKonservasi. Yogyakarta, 30 Juli 2002. hal. III:1-35.

Utomo, M. 2012. Tanpa Olah Tanah: Teknologi Pengelolaan Pertanian Lahan Kering. Lembaga Penelitian Universitas Lampung. Bandar Lampung. $110 \mathrm{hlm}$.

Winarso, S. 20015. Kesuburan Tanah: Dasar Kesehatan dan Kualitas Tanah.Gava Media. Jogjakarta. $269 \mathrm{hlm}$. 